\title{
Słowo o Profesorze Andrzeju Sitarskim
}

\section{A few words about Professor Andrzej Sitarski}

Profesor Andrzej Sitarski urodził się 26 sierpnia 1950 roku w Bystrzycy Kłodzkiej. W latach 1957-1964 uczęszczał do Szkoły Podstawowej nr 1 i nr 5 w Bolesławcu, a w latach 1964-1968 do Liceum Ogólnokształcącego im. Władysława Broniewskiego w Bolesławcu. W szkole średniej Jego wychowawczynią była Waleria Bocian. W pamięci Profesora zachowała się ona jako postać niezwykła, czujna przewodniczka przez cały okres nauki. Waleria Bocian była pedagogiem emocjonalnie zaangażowanym $\mathrm{w}$ losy swoich podopiecznych, umiejącym wysłuchać i wesprzeć tych, którzy tego potrzebowali. Dla Jubilata to właśnie ona była autorytetem dydaktycznym, inspirowała do poznawania języka rosyjskiego i literatury rosyjskiej. Odnotować należy, że Liceum Ogólnokształcące im. Władysława Broniewskiego cieszyło się wysoką renomą ze względu na poziom kształcenia. Potwierdzeniem tego był fakt, że uczniowie szkoły regularnie znajdowali się w gronie finalistów Dolnośląskiej Olimpiady Naukowej Disce Puer, organizowanej corocznie w latach 1963-1981.

Jubilat już w czasach licealnych zdał sobie sprawę, że jest humanistą, jednak trapiły go wątpliwości dotyczące tego, jaki kierunek studiów wybrać. Zastanawiał się nad filologią rosyjską, germańską i polską. Ostatecznie uznał, że wybierze filologię rosyjską na Uniwersytecie Wrocławskim. W tamtejszym Instytucie Filologii Słowiańskiej pracowali wówczas liczni przedwojenni wykładowcy Uniwersytetu Lwowskiego. Instytutem kierował wybitny literaturoznawca prof. dr hab. Marian Jakóbiec. W trakcie studiów jedną z wielu wykładowczyń Andrzeja Sitarskiego była Janina Sidorska, wychowanka prof. Eleny Bryzgunowej - autorki opracowań z zakresu fonetyki i fonologii języka rosyjskiego. Jubilat uznawał Janinę Sidorską za autorytet w dziedzinie dydaktyki języka rosyjskiego. W 1973 roku Andrzej Sitarski obronił pracę magisterską Imena suŝstvitel'nye ženskogo roda s suffiksom -ical-nica $v$ sovremennom russkom âzyke przygotowaną pod kierunkiem prof. dr. hab. Marka Michajłowa.

W tym samym roku 1 września Andrzej Sitarski został zatrudniony na stanowisku lektora języka rosyjskiego w Zakładzie Dydaktyki Języka Rosyjskie- 
go w Instytucie Filologii Rosyjskiej i Słowiańskiej Uniwersytetu im. Adama Mickiewicza w Poznaniu. Nastąpiło to z rekomendacji prof. dr. hab. Zbigniewa Barańskiego, który pełnił wówczas funkcję dyrektora Instytutu Filologii Rosyjskiej i Słowiańskiej UAM oraz Instytutu Filologii Słowiańskiej Uniwersytetu Wrocławskiego. Od tego momentu Andrzej Sitarski przez sześć lat pracował jako lektor języka rosyjskiego. Był to czas, który poświęcił na intensywną praktykę dydaktyczną i doskonalenie umiejętności językowych. Odbył liczne podróże służbowe do Związku Radzieckiego, jak również staż dydaktyczny na Uniwersytecie Warszawskim pod czujnym okiem uznanych wykładowczyń języka rosyjskiego: Albiny Gołubiewej, Taisy Cwejman i Wiery Torzeckiej. Andrzej Sitarski podkreśla, że prowadził w tamtym czasie zajęcia praktyczne z języka rosyjskiego, korzystając z materiałów dydaktycznych ich autorstwa.

W 1979 roku Andrzej Sitarski zwrócił się do prof. Tadeusza Zdancewicza, ówczesnego dyrektora Instytutu Filologii Rosyjskiej i Słowiańskiej UAM, z prośbą o przeniesienie na stanowisko starszego asystenta w Zakładzie Języka Rosyjskiego. Wynikało to z podjętej decyzji o zintensyfikowaniu pracy naukowej i przystąpieniu do pisania rozprawy doktorskiej. Otrzymał odpowiedź pozytywną. Promotorem jego rozprawy doktorskiej został prof. dr hab. Albert Bartoszewicz. W poszukiwaniu materiałów do rozprawy doktorskiej Jubilat wyjechał na staż naukowy do Warszawy. Tam korzystał z księgozbiorów stołecznych bibliotek, m.in. Biblioteki Uniwersytetu Warszawskiego, i konsultował swoje postępy dotyczące tematu rozprawy doktorskiej z prof. Albertem Bartoszewiczem, który pracował wówczas na Uniwersytecie Warszawskim. Przed ukończeniem rozprawy doktorskiej Andrzej Sitarski opublikował trzy artykuły naukowe poruszające różne aspekty analizy lingwistycznej terminologii językoznawczej. Ukazały się one na łamach czasopisma „Studia Rossica Posnaniensia” i „Przeglądu Rusycystycznego". Rozprawę doktorską Polska i rosyjska terminologia językoznawcza w świetle zjawisk leksykalnych i stowotwórczych języka polskiego i rosyjskiego obronił 14 czerwca 1984 roku. W 1991 roku nakładem Wydawnictwa Naukowego Uniwersytetu im. Adama Mickiewicza w Poznaniu ukazała się jego monografia naukowa Pol'skaâ i russkaâ lingvističeskaâ terminologiâ $v$ svete slovoobrazovatel'nogo i leksičeskogo âvlenij, stanowiąca skrócony wariant rozprawy doktorskiej.

W drugiej połowie lat 80. Jubilat zaczął zastanawiać się nad problematyką, której mógłby poświęcić rozprawę habilitacyjną. Rozmawiał o tym z prof. Albertem Bartoszewiczem, który zwrócił jego uwagę na zagadnienie pragmatyki przysłówka w języku rosyjskim i polskim. W 1989 roku Profesor Andrzej Sitarski odbył półroczny staż naukowy na Uniwersytecie im. M. W. Łomonosowa w Moskwie. Tam badał problem funkcjonowania przysłówków we współczesnym języku rosyjskim oraz zagadnienie apelatywizacji nazw własnych w języku rosyjskim. 
W późniejszym okresie prof. Albert Bartoszewicz, już jako kierownik Zakładu Języka Rosyjskiego w Instytucie Filologii Rosyjskiej i Słowiańskiej UAM, regularnie organizował spotkania, których celem było omawianie problemów zgłębianych przez pracowników zakładu oraz aktywizowanie ich do działalności naukowej. W latach 1984-2001 Andrzej Sitarski opublikował 19 artykułów naukowych, z których 7 było poświęconych problematyce przysłówka. Rozprawa habilitacyjna Jubilata była poświęcona dwuaspektowości przysłówków na poziomie formy i treści, a w szczególności ich potencjału do kondensowania przekazu zawartego w komunikacie językowym. Celem było zbadanie specyfiki semantyki przysłówków na przykładzie różnych odmian stylistycznych rosyjskich tekstów.

W 1990 roku Profesor Sitarski objął stanowisko adiunkta, wkrótce został także zaproszony do Rady Wydziału Neofilologii UAM, której członkiem pozostał do 2020 roku. W latach 1993-1998 zajmował stanowisko wicedyrektora do spraw dydaktycznych w Instytucie Filologii Rosyjskiej.

Znaczną część 1999 i 2000 roku Jubilat poświęcił żmudnej pracy tłumaczeniowej, którą jednak wspomina niezwykle ciepło. Sporządził wówczas przekład autobiografii uznanej w świecie rosyjskiej śpiewaczki operowej Galiny Wiszniewskiej Galina. Historia mojego życia, wydany sumptem Teatru Wielkiego im. Stanisława Moniuszki w Poznaniu. W tym okresie Galina Wiszniewska często gościła w Poznaniu, dlatego też Profesor Andrzej Sitarski miał okazję osobiście ją poznać i konsultować z nią wątpliwości pojawiające się podczas tłumaczenia. Właśnie w związku z tą znajomością i tym przedsięwzięciem translatorskim Jubilat wkroczył do poznańskiego środowiska muzycznego. Przekład jego autorstwa został przyjęty entuzjastycznie zarówno w Polsce, jak i za granicą, szczególnie w środowisku Polonii kanadyjskiej i amerykańskiej, o czym Profesor Sitarski wspominał w wielu udzielonych po publikacji wywiadach. W rozmowie przeprowadzonej przez Romualda Połczyńskiego dla czasopisma „Ruch Muzyczny” Jubilat odniósł się do tezy postawionej przez szanowanego dziennikarza, że przygotowanie tego przekładu to dla tłumacza ,nie byle jaka przygoda”, stwierdzając, że było to „raczej jednak wielkie wyzwanie. Filologiczne, translatorskie i warsztatowe, nawet detektywistyczne"1.

Rozprawę habilitacyjną zatytułowaną Struktura $i$ funkcionirovanie narečij $v$ russkom âzyke novejšego vremeni (Wydawnictwo Naukowe UAM, 2001) Jubilat obronił 24 maja 2001 roku, a 1 lipca 2002 roku na podstawie decyzji Rektora UAM prof. dr. hab. Stefana Jurgi Andrzejowi Sitarskiemu nadano tytuł profesora uczelni. W tym czasie Profesor Sitarski na prośbę prof. dr. hab. Walentego Piłata, dyrektora Instytutu Słowiańszczyzny Wschodniej Uniwersytetu Warmińsko-Mazurskiego w Olsztynie, podjął współpracę z tym Instytutem. Został w nim zatrudniony na

\footnotetext{
'Zob. Romuald Połczyński, „Galina Wiszniewska o sobie”. Ruch Muzyczny, 14, 2000.
} 
stanowisku profesora nadzwyczajnego. Jubilat pracował także w Wyższej Szkole Języków Obcych w Świeciu nad Wisłą - był rektorem tej uczelni. Niemniej jednak, jak podkreśla, cała jego kariera naukowa i dydaktyczna pozostaje związana przede wszystkim z Zakładem Dydaktyki Języka Rosyjskiego (obecnym Zakładem Pragmatyki Komunikacyjnej Języków Obcych) i Zakładem Języka Rosyjskiego w Instytucie Filologii Rosyjskiej i Ukraińskiej UAM. Dnia 1 grudnia 2008 roku Jubilat objął stanowisko dyrektora Instytutu Filologii Rosyjskiej UAM, przemianowanego od 1 września 2016 roku na Instytut Filologii Rosyjskiej i Ukraińskiej, które piastował do 30 grudnia 2019 roku. Od 30 września 2013 do 30 września 2020 roku był też kierownikiem Zakładu Pragmatyki Komunikacyjnej Języków Obcych. Jubilat jest także członkiem Komitetu Słowianoznawstwa na Wydziale I Nauk Humanistycznych i Społecznych Polskiej Akademii Nauk - w 2015 roku został wybrany na czteroletnią kadencję po raz pierwszy, zaś w 2019 roku po raz drugi.

Instytut Filologii Rosyjskiej i Ukraińskiej UAM zawdzięcza Profesorowi Andrzejowi Sitarskiemu zapoczątkowanie wielu inicjatyw, które na stałe wpisały się do kalendarza wydarzeń uniwersyteckich. Był on pomysłodawcą etapu uczelnianego Ogólnopolskiego Konkursu Recytacji Poezji Rosyjskiej, odbywającego się w ramach Poznańskich Dni Kultury Wschodniosłowiańskiej „MiMoKi - Mińsk, Moskwa, Kijów", przy czynnym wsparciu dr Natalii Królikiewicz i dr. Romana Szubina. Pierwsza edycja tego konkursu miała miejsce w 2010 roku. Przy udziale Profesora Sitarskiego rozwinął swoją działalność teatr studencki Szutnik, którym z pełnym zaangażowaniem opiekowała się była studentka Profesora dr Grażyna Jatczak. Z inicjatywy Jubilata Instytut Filologii Rosyjskiej i Ukraińskiej podją współpracę z poznańskim oddziałem Związku Literatów Polskich. Zaowocowała ona wydaniem antologii poezji Jak podanie ręki w trzech wersjach językowych: rosyjskiej, ukraińskiej i białoruskiej. Efektem działań organizacyjnych Profesora Sitarskiego, prowadzonych wspólnie z dr. Aliaksandrem Raspopouem, było też spotkanie Sny i słowa o wolności z uznanym białoruskim poetą i działaczem politycznym Uładzimirem Niaklajeu, które odbyło się w 2016 roku. Przy wsparciu Profesora Sitarskiego zrealizowano wymianę studencką i kadrową z Irkuckim Uniwersytetem Państwowym, a także zorganizowano wyjazdy studenckie na dwutygodniowe kursy językowe do Sankt Petersburga. W ramach współpracy z mgr. Aleksandrem Gazarianem Instytut Filologii Rosyjskiej i Ukraińskiej objął patronatem kilka poznańskich szkół średnich, w których naucza się języka rosyjskiego, m.in. Zespół Szkół Budowlano-Drzewnych im. Bolesława Chrobrego, II Liceum Ogólnokształcące im. Generałowej Zamoyskiej i Heleny Modrzejewskiej i VI Liceum Ogólnokształcące im. Ignacego Jana Paderewskiego.

Na szczególne uznanie zasługuje rola, jaką Profesor Sitarski odegrał w ukonstytuowaniu się Zakładu Ukrainistyki w ramach Instytutu Filologii Rosyjskiej, a także powołaniu nowej specjalności - filologii ukraińskiej. Było to możliwe 
dzięki harmonijnemu współdziałaniu z kierowniczką Zakładu Ukrainistyki prof. Tetyaną Kosmedą. Do istotnych osiągnięć Zakładu zaliczyć należy zainicjowanie Międzynarodowego Konkursu Recytacji Poezji Ukraińskiej, którego pierwsza edycja miała miejsce w 2018 roku, jak również obchodów Święta Szewczenkowskiego, których punktem kulminacyjnym są studenckie prezentacje poetyckiej twórczości Tarasa Szewczenki.

Profesor Andrzej Sitarski jest autorem dwóch monografii naukowych, 62 artykułów naukowych opublikowanych w czasopismach i tomach zbiorowych, jak również trzech wydawnictw z zakresu dydaktyki języka rosyjskiego (dwóch kursów językowych i jednego słownika) oraz licznych przekładów z języka rosyjskiego i polskiego. Jego zainteresowania naukowe dotyczą problemów leksykologii, leksykografii, terminografii, a w ostatnim czasie językoznawstwa kognitywnego i kulturowego ze szczególnym uwzględnieniem konceptosfery literackiej i nieliterackiej i jej językowych realizacji. Jubilat wypromował ok. 200 prac licencjackich i magisterskich z zakresu badań porównawczych frazeologii polskiej i rosyjskiej, a także teorii i praktyki przekładu tekstów literackich i nieliterackich.

Obecnie Profesor Andrzej Sitarski jest opiekunem naukowym trojga doktorantów: Ekateriny Starodvorskiej, Dmitrija Lukianova i Katarzyny Kubeckiej. Pod jego kierunkiem zostały napisane i obronione 4 rozprawy doktorskie: Łukasza Małeckiego Kognitywna semantyka konceptu STRACH (na materiale wspótczesnej prasy rosyjskiej i ukrainskiej) (2012), Darii Słupianek-Tajnert Kognitywna analiza czasowników percepcji wzrokowej w języku rosyjskim i polskim (2015), Konrada Rachuta Postaci dyskursu w perspektywie tworzenia i tlumaczenia „poetonimów”. Na podstawie polskiego i rosyjskiego przekładu sagi o Harrym Potterze (2018) i Marianny Plakuevej-Olejniczak Strategie przekładu jako wypadkowa interakcja czynników świadomego wyboru tlumacza. Na przyktadzie polskich thumaczeń wczesnej poezji Borysa Pasternaka (2019).

Od 2002 roku Profesor Sitarski wystąpił jako recenzent w 14 postępowaniach doktorskich i 9 postępowaniach habilitacyjnych. Recenzowane rozprawy zostały obronione na Uniwersytecie Wrocławskim, Uniwersytecie Rzeszowskim, Uniwersytecie Łódzkim, Uniwersytecie Gdańskim, Uniwersytecie Śląskim w Katowicach, Uniwersytecie Szczecińskim i Uniwersytecie im. Adama Mickiewicza w Poznaniu.

Szczerze dziękując za nieoceniony wkład organizacyjny, naukowy i dydaktyczny w rozwój zarówno obecnego Instytutu Filologii Rosyjskiej i Ukraińskiej, jak i rusycystyki polskiej jako takiej, życzymy Profesorowi Andrzejowi Sitarskiemu pozostania w dobrym zdrowiu, odnajdywania nowych inspiracji i kontynuowania działalności na wszystkich wspomnianych polach. 